\title{
Grammatical Aspects in Tenseless Theory of Sinhala Language
}

\author{
T.M. Piyadigama \\ University of Moratuwa
}

February 3, 2019

\begin{abstract}
Studying tense-and-aspect systems is a major area in linguistic studies. There is no example for grammatical aspects in Sinhala language mentioned in the academic literature on grammar. There were several stages of the development of tense theories. In my previous work "There are no tenses in Sinhala Language" I verified that all the tense theories for Sinhala language fail and the verb categories which are misunderstood as tenses are actually not tenses. This article summarizes the result of my previous work and describes my novel formulation in formal linguistic terms. The result is to understand the aspectual nature of the Sinhala verbs.
\end{abstract}

\section{Introduction}

Tense and aspect are closely related but different concepts. Tense denotes a temporal reference to an event, situation or act represented by a verb. (For example, past-present-future, past-non past e.t.c.). Aspect denotes how which is expressed by the verb extends over time. There are two major aspects generally identified perfective and imperfective. Perfective aspect verbs represent the idea, situation or act expressed by it as a whole while imperfective aspect represents the internal composition of which is expressed. To explain further, imperfect aspect impress whether the expressed idea, situation or act is progressing, repeating or habitual. [Com85]

\section{History of Sinhala Grammar}

There are two stages of tense theories in Sinhala Language.

1. Three tense theory (Past, Present, Future)

2. Two tense theory (Past, non Past - sometimes past, future)

Three tense theory can be found since earliest grammar books (Siyabaslakara and Sidath Sanagarawa). Mr. Cumaratunge Munidasa, an elegant researcher in Sinhala language, identified that early three tense theory is flawed and formulated a two tense theory. 
The author of this article understood two tense theory is also flawed and proposed a tenseless theory in his article "There are no tenses in Sinhala language" published in Divaina newspaper. Readers interested in the argumentation to refute two tense theory and the historical evolution of the subject are advised to refer the above article.

The tenseless theory does not reject the division of verbal categories proposed by Mr. Cumaratunge but diverges with his tense based interpretation of those categories. Tenseless theory renames the so-called past and non-past categories as nimitha and animitha considering the actual functionality.

\section{Tenseless theory of Sinhala Language}

Tenseless theory suggests two verb categories: nimitha and animitha.

Following example explains these categories for verb stem - duva (run) in singular third person masculine gender

1. Nimithadivii (ya) - nimitha pure verb divve (ya) nimitha noun based verb

2. Animithaduva $(y a)=$ duvayi - animitha pure verb duvanne (ya) - animitha noun based verb

The next and most important step of the theory is to explain functionality of these two categories.

Animitha is used for event, situation or act to denote,

1. that it is progressive or continuous.

2. that is repetitive.

3. that it is possible to happen (or a possible alterity)

4. that it is a common state of a specific era.

(4th case is not a necessary. Same meaning can be obtained with nimitha. But animitha has also been used in literature. First three forms are necessary and the meaning will change if nimitha is used.)

5. Animitha is used in newspaper headlines.

Nimitha is used in all other occasions (where the act, event or situation expressed by the verb is taken whole as one unit).

5th case was introduced to newspaper tradition by Mr. Munidasa himself in 
accordance with the the English tradition of using simple present since the animitha category was misunderstood as present tense at that time. 5th case is now popular as a common practice so I included that also with other four.[Piy17]

Mr. Munidasa also elegantly identified 4th case before me and reported in his book 'Vyakarana Vivaranaya'. Being unaware of first three cases and being in the tense theory domain, he interpreted the 4th case as an exception to his two tense theory. The fact that there are exceptions to the tense theory is understood even in the three tense theory era because 'Sidath Sangarawa' and other several grammar books provide examples to the existence of exceptions ('Kiriya Perali') [DA52] though an interpretation or analysis in the nature of those exeptions was never presented. The existence of exeptions was identified, accepted and then paradoxically neglected before the tenseless theory. The article "There is no tenses in Sinhala Language" discusses the nature of the exceptions and identifies them as a result of a flawed theory.

\section{Examples for Nimitha Animitha Functionality}

\subsection{Animitha}

1st case: Continuous or progressive

Eeye ude ma ohu dakina wita ohu pasalata (duwayi).

He was running to school when I saw him yesterday.

2nd case: Repetitive

Gaswala kola (wateyi).

Leaves of the trees fall / fell repetitively. 3rd case:

Possible alterity

Anith pakshayen illuwe nam ohu giya wara chandayen (dinanne) ya.

He would have won the last election if he represented the other party.

4th case: Common state of a specific era.

Gal yugaye minissu gal guhawala jeewath (wethi).

People of Stone age lived in caves.

5th case: Headlines

Yuddaya (arambeyi). 
War begins.

\subsection{Nimitha}

Thaththa gedara (awe) ya.

Father came home.

The nimitha or animitha verbs are in parentheses.

\section{Aspectual Nature of Nimitha Animitha}

Nimitha and animitha verb categories have an aspectual basis rather than a tense basis.

Functionality of nimitha, to consider the expressed action, situation, event as a unit, is the nature of perfective aspect.

Animitha is related to imperfective aspect. 1 st and 2 nd cases are related to continuous and habitual (repetitive) aspect respectively. These two aspects are subcategories under imperfective aspect. The third and fourth cases also related to aspect and clearly distinct from tense. Non of these five cases represents a time reference. First four cases express how the event, situation or act extends over time. Therefore the tenseless theory of Sinhala language not only refute grammatical tenses but also identifies grammatical aspects in Sinhala language.

I refrained from strictly translating nimitha and animitha to perfective and imperfective respectively because third case cannot be classified into conventional imperfective aspect.

\section{Special Remarks}

The term grammatical tense means the grammatical morphological tense in this article. This terminology persisted in two tense and three tense theories. Though tenseless theory is discussed here in this traditional discourse the tenseless theory can be broadened to understand the complete domain. As a summary, non morphological tenses also do not exist in Sinhala language and the nimitha animitha verb formation in various forms can be identified. This will be explained in our next steps.

Refuting the greatest misconception in Sinhala Grammar (and another misconception in the field of tense and aspect systems - undoubtedly dealt with misconception and conflations throughout the history) we can now clearly say that Sinhala is a tenseless language. Burmese, Dyirbal, Chinese, Malay are some other tenseless languages identified upto now. 


\section{References}

[Com85] Bernard Comrie. Tense, volume 17. Cambridge university press, 1985.

[DA52] James De Alwis. The Sidath Sangarawa: A Grammar of the Sinhalese Language Trasnlated Into English, with Introduction, Notes, and Appendices. Ceylon Government Press, 1852.

[Piy17] Thamalu Maliththa Piyadigama. There are no tenses in sinhala language. Divaina Watamadala, 2017. 